\title{
TEMPAT PERTUNJUKAN KESENIAN KHAS TIONGHOA DI GLODOK
}

\author{
Faustinus Hadinata Muliawan ${ }^{1)}$, Suwardana Winata ${ }^{2)}$ \\ 1) Program Studi S1 Arsitektur, Fakultas Teknik, Universitas Tarumanagara, faustinusmuliawan@gmail.com \\ 2) Program Studi S1 Arsitektur, Fakultas Teknik, Universitas Tarumanagara, danarsitek@gmail.com
}

\begin{abstract}
Abstrak
Glodok dikenal sebagai pecinan di Jakarta, Mayoritas penduduk nya adalah kaum Tionghoa. Di kawasan Glodok ini didominasi oleh para pengerajin kesenian khas Tionghoa, seperti barongsai, liong, kaligrafi China, lukisan khas Tionghoa, kerajinan keramik, kesenian musik khas Tionghoa, pengerajin baju tradisional Tionghoa, dan juga banyak pabrik makanan tradisional China dalam skala rumahan. Mayoritas pengerajin seni adalah kaum lansia, karena mengerajin kesenian ini sudah menjadi bagian dari kehidupan berderma atau berbakti kepada Sang Pencipta dan juga kepada leluhur mereka, komunitas pengerajin seni ini adalah berbasis amal/tidak mengambil keuntungan. Oleh karena itu tujuan dari proyek ini adalah untuk menjaga keberlangsungan dari komunitas kesenian khas Tionghoa ini. Agar komunitas ini tetap mendapat pengakuan maka dibutuhkan sebuah wadah yang dapat mengelola komunitas ini agar lebih mendapat banyak perhatian dari penduduk di kawasan Glodok ini. Ide dari program yang direncanakan dalam proyek ini adalah menganut konsep dari hulu ke hilir, dimana di tempat ini dapat menjadi pusat budaya,pertunjukan dan rekreasi bagi penduduk Glodok dan sekitarnya. Hal ini diwujudkan dari program dalam proyek ini yang mulai dari pembuatan, memamerkan dan menampilkan hasil dari kesenian khas China ini, kemudian sampai pada akhir nya dapat diperlombakan dan dapat menjadi produk kerajinan seni secara komersil. Metode perancangan dan desain proyek ini mengambil inspirasi dari bangunan Tulou di Fujian, China yang kemudian di modifikasi lagi sesuai dengan konteks kota yang berlaku di kawasan Glodok.
\end{abstract}

Kata kunci: derma; glodok; pecinan; seni; tionghoa

\begin{abstract}
Glodok sub district is known as a Chinatown in Jakarta. The population in Glodok sub district are dominated by craftsmen of chinese arts, such as lion dance, liong, chinese calligraphy, chinese decorations, porcelain crafts, chinese music, chinese traditional clothes, and also various kinds of homemade chinese traditional food. The chinese art crafted are charity and worship to the gods. This Chinese traditional craftsman are unprofitable community. The goals of this project is for supporting the survival of this Chinese arts community. These communities needs facilities in order to get more attention from residents in Glodok sub district and greater. The idea of the program for this project is one stop cultural center concept, where this place can become a cultural place, exhibition, and recreation center for Glodok residents and the surroundings. In this project visitors can make, exhibit, and display the product and performance of the Chinese traditional art. In this place is possible to make a competition between each of traditional chinese art organization, for supporting the existence of each traditional Chinese art community. The product can be sold as commercial Chinese art works. The design method of this project are inspired by Tulou building in Fujian China, and has been modified according to the context of the city prevailing in the Glodok region.
\end{abstract}

Key words: art; chinese; chinatown; craft; glodok 


\section{PENDAHULUAN}

Glodok dikenal sebagai daerah pecinan di Jakarta khusus nya di Jakarta Barat, disebut pecinan karena dulunya kawasan Glodok merupakan tempat bermukim dan pusat perdagangan bagi masyarakat mayoritas kaum Tionghoa. Sampai saat ini pun walau sudah berada pada generasi ketiga masyarakat kelurahan Glodok ini masih tetap ditinggali oleh penduduk mayoritas keturunan Tionghoa, Serta selain kebudayaan akan berkumpul dan memiliki jiwa bersosialisasi yang tinggi mayoritas kaum Tionghoa ini juga memiliki banyak kesenian khas yang masih digeluti sampai sekarang di daerah kelurahan Glodok ini sebagai contoh adanya pengerajin seni wayang cokek, perkumpulan barongsai, perkumpulan liong, seni penulisan kaligrafi china, kesenian musik china dan betawi, penjualan film-film tionghoa peranakan dan betawi, pengerajin busana khas Tionghoa peranakan dan Betawi, pengerajin dan pembuat furniture khas Tionghoa, serta banyak nya pabrik makanan khas Betawi dan Tionghoa di perumahan warga Glodok ini. Namun karakter yang muncul di daerah Glodok ini menimbulkan beberapa masalah seperti ketidak tersediaan tempat bagi para ahli kesenian yang ada di daerah Glodok ini untuk menampilkan kebudayaan Tionghoa peranakan ini selain pada hari raya, hal ini menjadi permasalahan karena sejatinya mayoritas warga Tionghoa di kelurahan Glodok ini selalu memanfaatkan hari raya dimana pagelaran seni dari ahli kesenian Tionghoa peranakan ini menunjukan berbagai pagelaran seni yang sangat ramai dikunjungi khusus nya oleh penduduk Glodok setempat dan hal ini secara tidak sadar dapat menciptakan suatu social place namun social place disini merupakan social place yang tercipta musiman saja. Bagi penduduk di Glodok ini kegiatan mengerajin kesenian khas tradisional Tionghoa sudah menjadi bagian dari tradisi yang tercipta secara turun menurun, mayoritas pengrajin nya adalah kaum lansia, hal ini dikarenakan tradisi mengrajin dan mempertunjukan kesenian tradisional khas Tionghoa ini adalah bentuk dari derma atau bakti yang secara kepercayaan sama hal nya seperti kepercayaan sebagai jalan mendekatkan diri kepada sang pencipta, sehingga ada sejarah yang mengatakan bahwa demi dapat menyambung hidup dari seni tradisional Tionghoa ini setiap komunitas yang ada di kecamatan Glodok ini umum nya mencari dana melalui pembukaan pasar malam yang menyajikan berbagai hasil kerajinan seni, dan makanan-makanan khas tradisional Tionghoa serta dari cara menggelar acara pementasan seni.

Namun dalam kenyataan nya pementasan seni semakin hari semakin sulit dikarenakan faktor ketidaktersediaanya tempat, sampai kepada unsur sulit nya mencari generasi penerus dari kesenian tradisional Tionghoa ini karena semakin banyak yang tidak mengenal dan tidak mengetahui adanya komunitas pengrajin kesenian tersebut di daerah glodok. Oleh karena itu tujuan dari proyek ini adalah untuk menjaga keberlangsungan dari komunitas kesenian khas Tionghoa ini. Agar komunitas ini tetap mendapat pengakuan maka dibutuhkan sebuah wadah yang dapat mengelola komunitas ini agar lebih mendapat banyak perhatian dari penduduk di kawasan Glodok ini. Ide dari program yang direncanakan dalam proyek ini adalah menganut konsep dari hulu ke hilir, dimana di tempat ini dapat menjadi pusat budaya,pertunjukan dan rekreasi bagi penduduk Glodok dan sekitarnya. Hal ini diwujudkan dari program dalam proyek ini yang mulai dari pembuatan, memamerkan dan menampilkan hasil dari kesenian khas China ini, kemudian sampai pada akhir nya dapat diperlombakan dan dapat menjadi produk kerajinan seni secara komersil.

\section{KAJIAN LITERATUR}

The Third Place Mengacu pada Oldenburg (1999) dengan konsep dari third place, iya mengemukakan bahwa third place itu adalah sebagai pembentuk ruang sosial, pengertian third place itu sendiri secara lebih spesifik menurut Oldenburg adalah tempat untuk orang yang ingin mengobati stress kesepian dan keterasingan tidak berhenti sampai disitu saja melainkan third place ini juga dapat menjadi tempat untuk bersantai dan yang berkunjung dapat merasa terhibur serta mendapat ketenangan serta kebahagiaan 
Third place ini sebagai tempat penunjang dari first place dan second place sebagai pembuka jati diri yang bertujuan untuk bersosialisasi di dalam nya, Oldenburg mengatakan bahwa ada 8 buah karakter dari third place ini sebagai berikut : neutral ground, leveller, conversation is the main activity, accessibility and accommodation, the regulars, low profile, mood is playful, dan a home away from home

\section{Neutral ground:}

- Orang mudah bergabung kapan pun mereka mau

- Orang orang dapat datang dan pergi tanpa ada aturan yang mengikat

- Tidak ada tuan rumah yang menjadi mayoritas atau ditinggikan dan harus nyaman di rumah sendiri

\section{Leveller :}

- Penghapusan semua posisi dan pangkat

- Penyamarataan seluruh kalangan ketika berada di tempat itu

- Siapa pun dapat mengakses

- Tujuan daripada tempat itu adalah kegembiraan, dan kelegaan

\section{Conversation is main activity :}

- Pembicaraan yang terjadi harus baik

- Tempat ini harus hidup, penuh warna dan menarik

- Tidak boleh ada gadget yang terlalu mengganggu dan musik yang terlalu keras

\section{Accessibility and accommodation :}

- Tempat harus memungkinkan dikunjungi walau hanya sendiri

- Siang-malam harus dapat menggaransi akan ada kerabat yang datang ke tempat itu baik disengaja maupun tidak sengaja

- Akses harus mudah dijangkau khusus nya untuk pejalan kaki

- Jika memungkinkan harus dapat diakses 24 jam

- Reguler:

- Yang menarik bukan apa yang disediakan dari tempat ketiga ini namun apa yang disediakan dari pengunjungnya

The regulars :

Harus ada pelanggan tetap

- Yang menarik bukan apa yang disediakan tempat itu melainkan apa yang disediakan oleh pengunjung nya itu sendiri

- Harus didominasi oleh pengunjung tetap

\section{A low profile :}

- Tempat ketiga harus bersifat polos

- Tempat di desain setara dengan masyarakat yang ada di tempat itu, tidak boleh nampak terlalu megah atau agung

\section{The mood is playful :}

- Tempat harus menyenangkan untuk dikunjungi

- Harus dapat membuat orang ingin berkunjung terus menerus

Home far from home :

- Rumah : pengaturan pribadi dan tingkat privasi lebih tinggi jika rumah dalam tempat ketiga adalah ruang public

Ruang Terbuka

\section{Sejarah Barongsai}

Menurut kutipan yang dikutip dari artikel berjudul Kesenian Barongsai di website tionghoa.info, kesenian barongsai mulai populer di zaman dinasti Selatan-Utara (Nan Bei) tahun 420-589 Masehi. Kala itu pasukan dari raja Song Wen Di kewalahan menghadapi serangan pasukan gajah raja Fan Yang dari negeri Lin Yi. Seorang panglima perang bernama Zhong Que membuat tiruan boneka singa untuk mengusir pasukan raja Fan itu. Ternyata upaya itu sukses hingga akhirnya tarian barongsai melegenda. 


\section{Fungsi Barongsai}

- Menghilangkan energi negatif - Suara yang nyaring dari drum dan gembrengan akan menyucikan atau membersihkan sebuah daerah/tempat yang chi/energi negatif dan jelek, menjadi energi yang baru dan bagus.

- Mengusir roh halus yang tidak baik - Kekuatan dari tarian dan keberadaan dari barongsai akan cukup untuk mengusir roh jahat keluar dari lokasi, dan memastikan bahwa usaha yang Anda kerjakan lebih sukses.

- Membawa Keberuntungan - Sebagai simbol kekuatan dan membawa keberuntungan, dengan keberadaan barongsai.

\section{Tarian dan gerakan}

Tarian Singa terdiri dari dua jenis utama yakni Singa Utara yang memiliki surai ikal dan berkaki empat. Penampilan Singa Utara kelihatan lebih natural dan mirip singa ketimbang Singa Selatan yang memiliki sisik serta jumlah kaki yang bervariasi antara dua atau empat. Kepala Singa Selatan dilengkapi dengan tanduk sehingga kadangkala mirip dengan binatang 'Kilin'.

Gerakan antara Singa Utara dan Singa Selatan juga berbeda. Bila Singa Selatan terkenal dengan gerakan kepalanya yang keras dan melonjak-lonjak seiring dengan tabuhan gong dan tambur, gerakan Singa Utara cenderung lebih lincah dan penuh dinamika karena memiliki empat kaki.

Ada berbagai cara untuk memainkan barongsai, namun masing-masing mengikuti pola dasar yang sama. Delapan elemen dasar dalam barongsai adalah : Tidur, Membuka, Bermain, Pencarian, Berkelahi, Makan, Penutup, dan Tidur. Tarian dapat diperpanjang, atau mungkin keluar dari kebiasaan bermain. Tarian singa juga diiringi oleh musik besar berupa drum, gong dan gembrengan, Pada acara seremoni sering ditambahi dengan bunyi petasan.

Satu gerakan utama dari tarian Barongsai adalah gerakan singa memakan amplop berisi uang yang disebut dengan istilah 'Lay See'. Di atas amplop tersebut biasanya ditempeli dengan sayuran selada air "Chai Chin", yang melambangkan hadiah bagi sang Singa. Proses memakan 'Lay See' ini berlangsung sekitar separuh bagian dari seluruh tarian Singa.

\section{Tari Naga/Liong}

Menurut kutipan yang dikutip dari artikel berjudul tarian naga di website tionghoa.info Tarian Naga (Hanzi : 舞龙; pinyin : wŭ lóng) atau disebut juga Liong di Indonesia adalah suatu pertunjukan dan tarian tradisional dalam kebudayaan masyarakat Tionghoa. Seperti juga Tarian Singa atau Barongsai, tarian ini sering tampil pada waktu perayaan-perayaan tertentu. Orang Tionghoa sering menggunakan istilah 'Keturunan Naga'(Hanzi : 龙的传人; pinyin : lóng de chuán rén) sebagai suatu simbol identitas etnis.

Dalam tarian ini, satu regu memainkan naga yang diusung dengan belasan tongkat. Penari terdepan mengangkat, menganggukkan, menyorongkan dan mengibas-kibaskan kepala naga tersebut yang merupakan bagian dari gerakan tarian yang diarahkan oleh salah seorang penari. Terkadang bahkan kepala naga ini bisa mengeluarkan asap dengan menggunakan peralatan pyrotechnic.

Para penari menirukan gerakan-gerakan makhluk naga ini membuat gerakan berkelok dan berombak. Gerakan-gerakan ini secara tradisional melambangkan peranan historis dari naga yang menunjukkan kekuatan yang luar biasa dan martabat yang tinggi. Tarian naga juga merupakan salah satu suguhan atraksi pada acara hari perayaan Imlek di kawasan pecinan seluruh dunia. Naga dipercaya bisa membawa keberuntungan untuk masyarakat karena kekuatan, martabat, kesuburan, kebijaksanaan dan keberuntungan yang dimilikinya. Penampilan naga terlihat gagah berani, namun tetap memiliki watak yang penuh kebajikan. 
Hal-hal inilah yang pada akhirnya menjadikannya lambang lencana untuk mewakili kekuasaan kekaisaran.

Tari Naga ini berasal dari zaman Dinasti Han (tahun 180-230 SM) dan dimulai oleh orangorang Tiongkok yang memiliki kepercayaan dan rasa hormat yang besar terhadap naga. Dipercaya bahwa pada mulanya tarian ini adalah bagian dari kebudayaan pertanian dan masa panen, disamping juga sebagai salah satu metode untuk menyembuhkan dan menghindari penyakit. Tarian ini sudah menjadi acara populer di zaman Dinasti Song (960-1279 M) dimana acara ini telah menjadi sebuah kebudayaan rakyat dan, seperti barongsai; juga sering tampil pada perayaan-perayaan yang meriah. Corak naga dibuat dengan menggabungkan gambarangambaran dari berbagai hewan yang lumrah ditemui. Naga ini kemudian berkembang menjadi sebuah makhluk dunia dongeng yang dipuja dalam kebudayaan Tiongkok.

Bentuk fisiknya merupakan gabungan dari bagian fisik berbagai hewan, diantaranya tanduk dari rusa jantan, telinga dari banteng, mata dari kelinci, cakar dari harimau dan sisik dari ikan; semuanya melengkapi tubuhnya yang mirip dengan tubuh ular raksasa. Dengan ciri-ciri ini, naga dipercaya sebagai makhluk amfibi dengan kemampuan untuk bergerak di tanah, terbang di udara dan berenang di laut; memberikan mereka peranan sebagai penguasa langit dan hujan. Para kaisar di Tiongkok kuno menganggap diri mereka sendiri sebagai naga. Oleh karenanya, naga dijadikan lambang dari kekuasaan kekaisaran. la melambangkan kekuatan magis, kebaikan, kesuburan, kewaspadaan dan harga diri.

Tarian Naga saat ini adalah sebuah karya penting dalam kebudayaan dan tradisi Tiongkok. Tarian ini telah tersebar di seluruh penjuru dunia; termasuk Indonesia. Karya ini menjadi sebuah pertunjukan seni khusus Tionghoa, melambangkan kedatangan keberuntungan dan kemakmuran dalam tahun yang akan datang bagi semua manusia di bumi.

\section{Wayang Potehi}

Menurut salmon Claudine Potehi berasal dari kata pou 布 (kain), te 袋 (kantong) dan hi 戯 (wayang). Wayang Potehi adalah wayang boneka yang terbuat dari kain. Sang dalang akan memasukkan tangan mereka ke dalam kain tersebut dan memainkannya layaknya wayang jenis lain. Kesenian ini sudah berumur sekitar 3.000 tahun dan berasal dari Tiongkok.

Menurut legenda, seni wayang ini ditemukan oleh pesakitan di sebuah penjara. Lima orang dijatuhi hukuman mati. Empat orang langsung bersedih, tetapi orang kelima punya ide cemerlang. Ketimbang bersedih menunggu ajal, lebih baik menghibur diri. Maka, lima orang ini mengambil perkakas yang ada di sel seperti panci dan piring dan mulai menabuhnya sebagai pengiring permainan wayang mereka. Bunyi sedap yang keluar dari tetabuhan darurat ini terdengar juga oleh kaisar, yang akhirnya memberi pengampunan.

Menurut sejarah, diperkirakan jenis kesenian ini sudah ada pada masa Dinasti_Jin 晉朝 (265-420 Masehi) dan berkembang pada Dinasti_Song 宋朝 (960-1279). Wayang Potehi masuk ke Indonesia (dulu Nusantara) melalui orang-orang Tionghoa yang masuk ke Nusantara pada sekitar abad 16 sampai 19. Data yang sahih berupa catatan awal tentang wayang Potehi di Indonesia, berasal dari seorang Inggris bernama Edmund Scott. Dia pergi ke Banten 2 kali, antara 1602 dan 1625. la menyebutkan, pertunjukan sejenis opera, yang diselenggarakan bila jung-jung akan berangkat ke atau bila kembali ke Tiongkok. la mengamati dengan teliti, bahwa pertunjukan ini berhubungan dengan penyembahan dan bahwa biarawan-biarawan mempersembahkan kurban, dan bersujud di tanah sebelum persiapan. Scott menuliskan bahwa "mereka sangat menyukai sandiwara dan nyanyian, tetapi suara mereka adalah yang paling jelek yang akan didengar orang. Sandiwara atau selingan itu mereka selenggarakan sebagai kebaktian kepada dewa-dewa mereka: pada permulaannya, mereka lazim membakar kurban, para pendetanya berkali-kali berlutut, satu demi satu. Sandiwara ini biasa diadakan, apabila mereka melihat jung atau kapal berangkat dari Banten ke Tiongkok. Sandiwara ini kadang-kadang mulai pada tengah hari dan baru berakhir keesokan paginya, biasanya di jalan terbuka, di panggung yang didirikan untuk maksud itu." 
Penjelajah-penjelajah 1-2 abad kemudian menggambarkan bahwa teater ini yang asli dari Tiongkok, sudah mapan di masyarakat-masyarakat perantau di kota utama pada masa itu. Sayangnya, hanya sedikit keterangan bahasa yang dipakai dalam pertunjukan itu. Juga tidak terdapat teater boneka sarung dari Fujian Selatan, yang dikenal dengan nama po-te-hi, yang kini masih ada di Jawa Timur dan Jawa Tengah.Pada abad ke-18, seorang Jerman yang bernama Ernst Christoph Barchewitz (yang tinggal selama 11 tahun di Jawa) menunjukkan bahwa ketika ia melihatnya di Batavia pertunjukan-pertunjukan ini diselenggarakan dalam bahasa Tionghoa. Bukan sekadar seni pertunjukan, Wayang Potehi bagi etnik Tionghoa memiliki fungsi sosial serta ritual. Tidak berbeda dengan wayang-wayang lain di Indonesia.

Beberapa lakon yang sering dibawakan dalam Wayang Potehi adalah Si Jin Kui 薛仁貴 (Ceng Tang 征東 dan Ceng Se 征西), Hong Kiam Chun Chiu 鋒劍春秋, Cu Hun Cau Kok 慈雲走 國, Lo Thong Sau Pak 羅通掃北 dan Pnui Si Giok 方世玉. Setiap wayang bisa dimainkan untuk pelbagai karakter, kecuali Koan Kong 關公, Utti Kiong 尉遲恭, dan Thia Kau Kim 程交金, yang warna mukanya tidak bisa berubah.

\section{Lakon}

Dulunya Wayang Potehi hanya memainkan lakon-lakon yang berasal dari kisah klasik Tiongkok seperti legenda dinasti-dinasti yang ada di Tiongkok, terutama jika dimainkan di kelenteng. Akan tetapi saat ini Wayang Potehi sudah mengambil cerita-cerita di luar kisah klasik seperti novel Se Yu 西遊記 (Pilgrimage to the West) dengan tokohnya Kera Sakti yang tersohor itu. Pada masa masuknya pertama kali di Nusantara, wayang potehi dimainkan dalam dialek Hokkian. Seiring dengan perkembangan zaman, wayang ini pun kemudian juga dimainkan dalam bahasa Indonesia. Oleh karena itu para penduduk non-Tionghoa pun bisa menikmati cerita yang dimainkan.

Menariknya, ternyata lakon-lakon yang kerap dimainkan dalam wayang ini sudah diadaptasi menjadi tokoh-tokoh di dalam ketoprak. Seperti misalnya tokoh Si Jin Kui 薛仁貴 yang diadopsi menjadi tokoh Joko Sudiro. Atau jika Anda penggemar berat ketoprak, mestinya tidak asing dengan tokoh Prabu Lisan Puro yang ternyata diambil dari tokoh Li Si Bin 李世民, kaisar kedua Dinasti Tong 唐朝 (618-907).

Alat musik Wayang Potehi terdiri atas gembreng/lo 鑼, kecer/simbal 鑔 cheh dan 鈸 puah, suling/phin-a 笛仔， (gitar/gueh-khim 月琴), rebab/hian-a 絃仔, tambur/kou 鼓 , terompet/ai-a 噯仔, dan piak-kou 逼鼓. Alat terakhir ini berbentuk silinder sepanjang 5 sentimeter, mirip kentongan kecil penjual bakmi, yang jika salah pukul tidak akan mengeluarkan bunyi "trok"-"trok" seperti seharusnya.

\section{Gambang Kromong}

Menurut artikel yang diambil dari situs pemerintah kota Jakarta, Gambang kromong (atau ditulis gambang keromong) adalah sejenis orkes yang memadukan gamelan dengan alatalat musik Tionghoa, seperti sukong, tehyan, dan kongahyan. Sebutan gambang kromong diambil dari nama dua buah alat perkusi, yaitu gambang dan kromong. Awal mula terbentuknya orkes gambang kromong tidak lepas dari seorang pemimpin komunitas Tionghoa yang diangkat Belanda (kapitan Cina) bernama Nie Hoe Kong (masa jabatan 1736-1740)

Bilahan gambang yang berjumlah 18 buah, biasa terbuat dari kayu suangking, huru batu, manggarawan atau kayu jenis lain yang empuk bunyinya bila dipukul. Kromong biasanya dibuat dari perunggu atau besi, berjumlah 10 buah (sepuluh pencon). Tangga nada yang digunakan dalam gambang kromong adalah tangga nada pentatonik Cina ${ }^{[1]}$, yang sering disebut salendro Cina atau salendro mandalungan. Instrumen pada gambang kromong terdiri atas gambang, kromong, gong, gendang, suling, kecrek, dan sukong, tehyan, atau kongahyan sebagai pembawa melodi. 
Orkes gambang kromong merupakan perpaduan yang serasi antara unsur-unsur pribumi dengan unsur Tionghoa. Secara fisik unsur Tionghoa tampak pada alat-alat musik gesek yaitu sukong, tehyan, dan kongahyan. Perpaduan kedua unsur kebudayaan tersebut tampak pula pada perbendaharaan lagu-lagunya. Di samping lagu-lagu yang menunjukkan sifat pribumi, seperti lagu-lagu Dalem (Klasik) berjudul: Centeh Manis Berdiri, Mas Nona, Gula Ganting, Semar Gunem, Gula Ganting, Tanjung Burung, Kula Nun Salah, dan Mawar Tumpah dan sebagainya, dan lagu-lagu Sayur (Pop) berjudul: Jali-jali, Stambul, Centeh Manis, Surilang, Persi, Balo-balo, Akang Haji, Renggong Buyut, Jepret Payung, Kramat Karem, Onde-onde, Gelatik Ngunguk, Lenggang Kangkung, Sirih Kuning dan sebagainya, terdapat pula lagu-lagu yang jelas bercorak Tionghoa, baik nama lagu, alur melodi maupun liriknya, seperti Kong Ji Liok, Sip Pat Mo, Poa Si Li Tan, Peh Pan Tau, Cit No Sha, Ma Cun Tay, Cu Te Pan, Cay Cu Teng, Cay Cu Siu, Lo Fuk Cen, dan sebagainya.

Lagu-lagu yang dibawakan pada musik gambang kromong adalah lagu-lagu yang isinya bersifat humor, penuh gembira, dan kadangkala bersifat ejekan atau sindiran. Pembawaan lagunya dinyanyikan secara bergilir antara laki-laki dan perempuan sebagai lawannya.

Gambang kromong merupakan musik Betawi yang paling merata penyebarannya di wilayah budaya Betawi, baik di wilayah DKI Jakarta sendiri maupun di daerah sekitarnya (Jabotabek). Jika terdapat lebih banyak penduduk peranakan Tionghoa dalam masyarakat Betawi setempat, terdapat lebih banyak pula grup-grup orkes gambang kromong. Di Jakarta Utara dan Jakarta Barat, misalnya, terdapat lebih banyak jumlah grup gambang kromong dibandingkan dengan di Jakarta Selatan dan Jakarta Timur.

Dewasa ini juga terdapat istilah "gambang kromong kombinasi". Gambang kromong kombinasi adalah orkes gambang kromong yang alat-alatnya ditambah atau dikombinasikan dengan alat-alat musik Barat modern seperti gitar melodis, bas, gitar, organ, saksofon, drum dan sebagainya, yang mengakibatkan terjadinya perubahan dari laras pentatonik menjadi diatonik tanpa terasa mengganggu. Hal tersebut tidak mengurangi kekhasan suara gambang kromong sendiri, dan lagu-lagu yang dimainkan berlangsung secara wajar dan tidak dipaksakan.

\section{Kaligrafi China}

Menurut Deng Sanmu 鄧散木, dan Shufa Xuexi Bidu書法學習必讀Kaligrafi adalah seni menulis tanda-tanda bahasa. Kaligrafi Cina ditandai dengan orisinalitas dan kekayaan tulisan Cina. Kaligrafi Cina memungkinkan bidang ekspresi artistik yang sangat luas. Kaligrafi Cina yang paling terkenal adalah salah satu yang menulis dengan kuas. Anak-anak sekolah belajar kaligrafi Cina melalui sinogrammes dengan bolpoin atau pena pena : kaligrafi ini disebut pena kaligrafi ( bukan nama yang sangat mengejutkan itu benar!) Mereka yang kaligrafi dengan kuas umumnya tidak baik pada kaligrafi pena dan sebaliknya, itu adalah mather fleksibilitas pergelangan tangan. Pada zaman kuno, karakter Cina yang terukir di tulang sapi atau kurakura kerang, kemudian perunggu. Kemudian mereka membuat buku dengan bilah bambu yang terhubung. Ini tentu menggunakan bulu bambu dan jelaga hitam untuk tinta. Bulu-bulu bambu masih digunakan kadang-kadang.

Brush kaligrafi dilakukan pada kertas beras atau sutra ( lebih rapuh ). Hardware dari kaligrafi ini disebut Empat harta Studi: Sikat, kertas, tinta , dan batu tinta. Tinta dalam bentuk tongkat yang digosokkan pada batu tinta dengan air untuk mendapatkan cairan tinta. Sekarang , tinta dalam botol, jauh lebih nyaman dan kualitas yang baik. Namun metode ini tidak memiliki kepadatan yang sesuai. Baik kaligrafi secara tradisional mencerminkan tingkat budaya melek huruf. Seorang dokter yang baik harus menjadi kaligrafer yang baik ( gloups!) Dan pemeriksaan untuk menjadi pejabat kekaisaran lebih menekankan pada kaligrafi calon dari pada isi salinan. Sejarah tulisan Cina ( lebih dari 3000 tahun!) Telah mengembangkan banyak gaya kaligrafi. Selain itu, karakter Cina memiliki berbagai ejaan : sekitar 3 oleh karakter. Karakter kebahagiaan memiliki seratus ejaan yang berbeda. Kaligrafi sudah memiliki berbagai 
kemungkinan. Hal ini juga dapat bervariasi selama penuh dan longgar untuk mengekspresikan perasaan mereka. Ini berbeda mungkin karakter kaligrafi teks untuk memperkuat atau mengubah maknanya. Pesan bahwa kaligrafi Cina bisa sangat luas. Untuk mempelajari kaligrafi Cina, lebih baik untuk mengetahui dasar-dasar tulisan Cina, selain itu akan belajar di tempat kerja. Kita mulai dengan mempelajari garis dasar, kemudian menggambar karakter dalam gaya biasa. Kemudian Anda mempelajari gaya kursif dan akhirnya gaya rumput, sangat kursif. Orang Cina mengatakan bahwa gaya biasa seperti berdiri, gaya kursif adalah seperti berjalan dan gaya rumput seperti menjalankan.

\section{Aktivitas Hidup Positif Kaum Tionghoa Sebagai Bentuk Bakti}

Tidak Lupa Berderma Salah satu kebiasaan yang selalu disorot mengenai kehidupan sosial masyarakat Tionghoa di Nusantara adalah kehidupan religius mereka. Namun, para sejarawan jarang ada yang melihat salah satu kebiasaan lain masyarakat Tionghoa yang cukup menarik yaitu menyisihkan sebagian penghasilannya untuk berderma. Ada dua jenis kegiatan berderma dalam kehidupan masyarakat Tionghoa (1) berderma untuk penguatan institusi, organisasi, perkumpulan ataupun kegiatan (2) berderma untuk sosial. Keberlangsungan dan keberlanjutan sebuah perkumpulan Tionghoa pada awal abad ke-20 salah satunya diakibatkan oleh faktor derma. Jaringan antar masyarakat peranakan dikuatkan untuk sama-sama membangun sebuah organisasi perkumpulan demi mewujudkan kehidupan masyarakat Tionghoa yang lebih baik.

Bentuk derma sendiri macam-macam, ada yang melalui derma secara umum, resmi menyumbang kepada perwakilan organisasi. Ada yang melalui semacam pertunjukkan kesenian amal dan ada pula yang membuka pasar malam. Pada koran-koran Tionghoa sering sekali diberitakan mengenai pendermaan warga Tionghoa kelas menengah untuk mendukung sebuah kegiatan. Salah satu artikel di Sin Po, memperlihatkan kegiatan derma warga Tionghoa untuk mendorong kemajuan THHK di berbagai daerah. Nominalnya macam-macam ada yang menyumbang kecil ada pula yang besar. Namun, rata-rata pada tahun 1914, jumlah derma untuk organisasi Tionghoa umumnya berkisar antara f 1- f 2,50 (Sin Po, 1914).

Derma memiliki kontribusi signifikan dalam keberlangsungan organisasi. Sebagai contoh perkumpulan yang sering menerima derma dari warga Tionghoa di Batavia adalah Tiong Hoa Hwee Koan (THHK) dan Union Makes Strength (UMS). UMS adalah perkumpulan olahraga kesebelasan sepakbola warga Tionghoa di Batavia yang terlibat dalam kompetisi sepakbola di Jawa pada awal abad ke-20. Berita mengenai perkembangan sepak bola di Batavia, khususnya UMS, sering diberitakan oleh majalah UMS, Tiong Hoa Oen Tong Hwee-Union Makes Strength.

Dalam majalah ini juga diberitakan apabila orang-orang Tionghoa yang berada di Batavia juga di tempat lain mendermakan sebagian uangnya untuk perkembangan keberlanjutan organisasi ini (Majalah Tiong Hoa Oen Tong Hwee-UMS, 1924). Begitu pula dengan THHK, dalam buku Nio Joe Lan, Riwayat 40 Tahun THHK-Batavia, banyak diceritakan tentang dermaderma dari warga Tionghoa Batavia untuk mendukung keberlangsungan kegiatan THHK. Derma pun tidak hanya diberikan dalam bentuk uang, tetapi ada yang dalam bentuk peralatan sekolah, pakaian dan perabotan. Kehidupan Sosial-Budaya Masyarakat Tionghoa di Batavia 1900an-1930an 27 Bentuk pengumpulan derma yang menarik adalah melalui pembukaan pasar malam. Pada 31 Januari 1936 di Medan, dibuka sebuah pasar malam besar di Centrale Pasar. Pemimpin pasar malam itu membuka sambutan dengan memakai bahasa Tionghoa yang diterjemahkan ke dalam bahasa Belanda oleh orang Tionghoa penerjemah. Dalam pidatonya ia mengatakan "bahwa pendapatan pasar malam ini akan disumbangkan ke perkumpulan amal Tionghoa dan sekolah-sekolah Tionghoa (Sin Po, 5 Februari 1936). Organisasi-organisasi yang sering menerima derma, tidak diam saja untuk mengumpulkan uang kas organisasi. Berbagai usaha kreatif dilakukan, seperti salah satunya dilakukan THHK. Dengan meniru konsep pasar malam, THHK mengadakan pasar malam amal untuk menambah kocek organisasi 


\section{Langgam Bangunan Tulou Fujian}

Menurut Gisling 唐戈 Tulou juga dijuluki bangunan bulat atau benteng bulat. Terutama terbesar di daerah Yung An, Nan Ching, Phing He yang berada di propinsi Fu Jian. UNESCO menggunakan term Fujian Tulou dalam situs mereka. Fujian Tulou adalah properti bangunan yang dibangun antara abad 15-20 di provinsi Fujian. Dapat dihuni sampai 800 orang. Tujuan pembangunan adalah untuk tujuan pertahanan diri.

Bangunan ini memiliki memiliki bentuk yang unik dan juga terkesan megah. Ada yang menyerupai kubus, ada juga yang bulat. Bentuk kubus dinamakan Fang Cai (Benteng Kotak), sedangkan yang bulat dinamakan Yuen Cai (Benteng Bulat). Sebagian besar bangunan ini didirikan 200 tahun lalu(pertengahan dinasti Qing). Menurut cerita dari generasi ke generasi, bangunan seperti ini didirikan untuk mencegah gangguan para perampok dan juga menghindari tekanan dari pihak kerajaan yang bobrok semasa itu. Biasanya orang satu keluarga atau beberapa keluarga tinggal bersama di suatu tempat.

Mereka membangun rumah di lembah atau daerah terpencil. Semula rumah ini dibuat saling menyambung dan melingkar menghadap ke dalam, kemudian ada yang membangun beberapa tingkat, gaya bangunan seperti ini terus bertahan hingga kini. Sebagian besar keluarga yang tinggal dalam bangunan ini adalah satu leluhur atau bermarga sama. Bila bertamu ke salah satu keluarga dalam benteng ini, maka semua penghuni didalamnya akan menganggap kita sebagai tamu kehormatan mereka juga.

Benteng keluarga macam ini saja ada 490 lebih di daerah Nan Ching. Belum lagi bangunan serupa di daerah Yung Ting dan sekitarnya. Sekalipun bentuk bangunan tidak sama, namun gaya dan coraknya tidak berbeda jauh. Semua bangunan ini terbuat dari tanah, pasir dan kapur, kerangka bangunan memakai bahan kayu dan bilah-bilah bamboo. Tinggi bangunan biasanya 3 sampai 4 tingkat. Atap ditutupi dengan lempengan tanah liat baker, nyatanya bangunan ini mampu bertahan lama. Dinding luar Tulou cenderung plain, tinggi dan terkesan seperti benteng, berbanding terbalik dengan interior bangunan yang didekorasi demi kenyamanan. Biasanya tiga sampai empat generasi tinggal, minimal menampung belasan keluarga, bahkan ada juga benteng bulat besar yang mampu menampung 70 keluarga yang bisa mencapai ratusan penghuni. Dinding biasanya semakin tebal semakin ke bawah.

Dinding paling bawah tebalnya mencapai 1.5 meter, sedangkan loteng paling atas hanya 0.8 meter. Dinding bangunan ini kokoh dan tahan terhadap hujan dan terik matahari. Ruangan dalam benteng umumnya memiliki bentuk dan ukuran serupa. Dalam sebuah benteng yang besar, ruangan yang ada bisa mencapai seratus ruangan lebih. Ruangan paling dasar biasanya dijadikan dapur atau gudang, tingkat dua dijadikan tempat penyimpanan makanan. Sedangkan tingkat 3 dan 4 untuk tempat tinggal. Dalam sebuah benteng, hanya ada satu pintu untuk keluar masuk. Ditengah bangunan ada sebuah halaman terbuka yang dipakai untuk ruang gerak seluruh penghuni, biasanya ada satu atau dua sumur di ruang terbuka.

Bangunan bulat ini hanya membutuhkan luas tanah sedikit, sedangkan pemanfaatan ruangan sangat efisien. Karena temboknya tebal, maka bisa mengurangi panas dan aman dari angin kencang. Hangat di musim dingin dan sejuk di musim panas, lagipula sinar matahari berkecukupan. Biasanya benteng-benteng ini memiliki kelebihan antara lain: kokoh, mudah menjaga keamanan, mudah mengatur penghuni, anti gempa, tahan air dan badai. Benteng-benteng yang ditemui saat ini banyak yang peninggalan Dinasti Qing dan Dinasti Ming. Tetapi banyak juga yang dibangun akhir-akhir ini. Sekalipun diterpa angin dan dihempas hujan serta gempa berkali-kali namun benteng ini tetap berdiri kokoh seperti gunung.

Beberapa tahun belakangan ini, sudah ada peneliti dan ahli dari Jepang, Amerika, Perancis, Denmark, Spanyol, dan juga berbagai Negara (sekitar 30 negara) datang ke China untuk meneliti dan melihat benteng-benteng ini. Setelah melihat sendiri bangunan bulat ini, mereka memuji dan mengatakan bahwa inilah 'harta terbesar sejarah bangunan China'. Untuk mengembangkan pariwisata dan menyedot turis, pihak Taiwan juga membangun "Negri Mini Thau Yuen". Mereka membuat bangunan mini dari benteng Cheng Chi yang ada di daerah Yung Ting China, lalu dipamerkan didekat bangunan Tembok Besar dan museum Ku Kung Taiwan yang telah dibuat mini modelnya. 


\section{METODE}

Banyaknya komunitas pengerajin kesenian tradisional khas Tionghoa yang tersebar dan tidak terorganisir dengan baik membuat pendataan menjadi suatu kendala dalam mendata jenis dan kegiatan setiap komunitas di daerah Glodok, maka dari itu metode schooling menjadi metode yang dipilih sehingga dapat membantu dalam menyusun kategori setiap kegiatan di kawasan Glodok ini.

\section{Lokasi}

kecamatan Taman Sari, kelurahan Glodok Jakarta barat

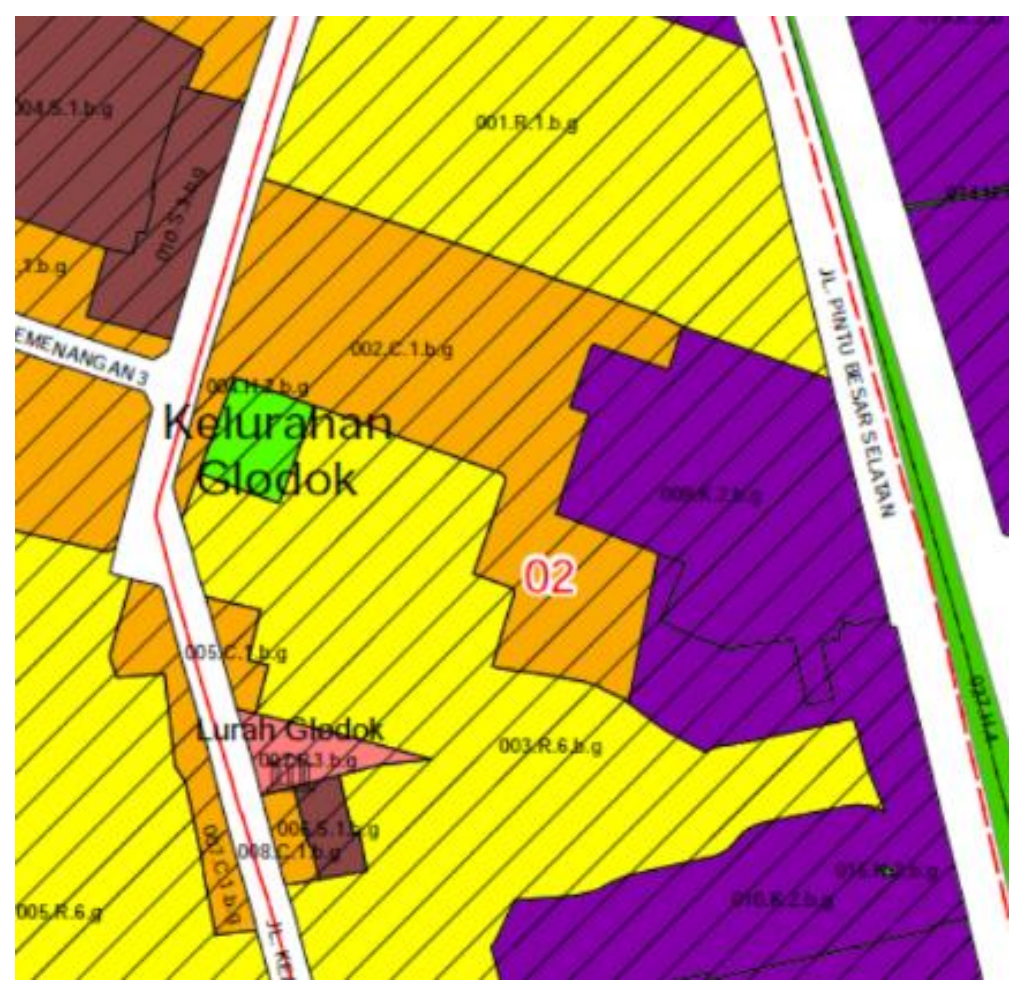

\section{Unit analisis}

Survey yang dilakukan dengan cara pengamatan, wawancara, serta diskusi

Analisis tapak dengan potensi-potensi tertentu

Literatur dan peraturan-peraturan pemerintah setempat

\section{Sampel}

Wawancara dengan warga sekitar yang berdagang dan bermukim di kelurahan Glodok

\section{Variabel}

Variabel bebas:

Umur, latar belakang pekerjaan, pendapatan, opini kebutuhan dari kawasan kelurahan Glodok Variabel terikat :

Lokasi tapak proyek

\section{Cara kerja riset}

Memilih lokasi untuk proyek terlebih dahulu

Menganalisa karakteristik dari kawasan tersebut

kemudian setelah pemilihan tapak, dan melihat potensi, ancaman, kelemahan, dan juga peluang maka didapatkan isu yang terpilih, kemudian setelah itu membuat survey lapangan dengan cara pengamatan, wawancara dan diskusi dengan warga sekitar

- setelah itu mencari teori-teori dan studi literatur pendukung

- mencari studi preseden sebagai contoh pengaplikasian dari proyek sejenis 


\section{Teknik pengumpulan data}

Mengumpulkan dan menganalisis data yang berasal dari survey serta literatur dan internet, sehingga dapat menjamin data dari sudut pandang yang berbeda

\section{Teknik analisa data}

Setelah data terkumpul maka penyaringan data harus dilakukan, jika yang berasal dari literatur dan juga internet maka dapat dijadikan sebagai data penguat dan pendamping dari pada data survey. Sedangkan yang berasal dari survey adalah data utama yang digunakan untuk mewakili keadaan kriteria gaya hidup dalam bekerja millennial di Indonesia. Data ini nanti nya akan meyakinkan dan juga digunakan untuk menyangkal teori yang ada dan dikaji dalam sudut pandang global.

\section{DISKUSI DAN HASIL}

\section{Permasalahan}

Isu mengenai karakter third place di kawasan Glodok ini sendiri menjadi suatu permasalahan bukan hanya sekedar wadah nya saja namun juga berkaitan langsung juga dengan keberlangsungan dari komunitas-komunitas pengrajin kesenian tradisional Tionghoa ini sebagai bentuk dari derma atau bakti, dan beberapa masalah nya adalah sebagai berikut :

- Esklusifitas dari komunitas-komunitas pengrajin kesenian khas Tionghoa

- Keterbatasan fasilitas dan tempat untuk pertunjukan dan juga latihan

- Eksistensi dari kesenian khas tradisional Tionghoa yang semakin menurun

- Sulitnya mencari generasi penerus dari kesenian tradisional Tionghoa ini

\section{Pembahasan}

\section{Pemilihan Lokasi}

Alamat: Jl. Kemurnian 4 kelurahan Glodok, kecamatan Taman sari, Jakarta barat

Luas: $4.850 \mathrm{~m}^{2}$

Zona: sub zona campuran

KDB: $75 \%$

KLB: 3

$\mathrm{KDH}: 30 \%$

KB: 4

KTB: $55 \%$

TIPE : DERET

\section{Desain}

Desain bangunan ini secara keseluruhan menganut desain dari unsur-unsur bangunan tradisional di pedesaan China, terutama terinspirasi dari bangunan tulou di provinsi Fujian China. Namun dibalik itu terdapat berbagai filosofi dalam pembentukan desain bangunan ini, salah satu nya adalah bentuk yang dipakai umumnya memiliki unsur melingkar / radial hal ini diambil dari bentuk-bentuk pola tarian tradisional Tionghoa yang memiliki pola radial, dan filosofi bangunan dengan bentuk melingkar yang memiliki symbol keseimbangan serta tak terputus memiliki makna tersendiri di kalangan orang Tionghoa. Material yang digunakan juga sangat di perhatikan sehingga baik dinding, kolom, ornament, sampai atap penutup bangunan nya jika disatukan dapat membentuk suatu nuansa khas China yang kental, seperti halnya penggunaan material yang didominasi oleh kayu dan batu serta ada beberapa aksen warna merah pada list kayu nya.

Kekhasan bangunan ini juga semakin terlihat pada penggunaan ornament pada kolom di lantai dasar nya, elevasi lantai dasar ke lantai dua nya dibuat sangat tinggi setinggi 7 meter dikarenakan untuk dapat mendapatkan nuansa yang maksimal dari penggunaan ornamen kolomnya, model ornamen kolom yang di tumpuk bergantian untuk melambangkan join dari 
kayu di negara tirai bambu tersebut, namun diadopsi dengan karakter yang lebih modern tanpa menghilangkan unsur utama nya.

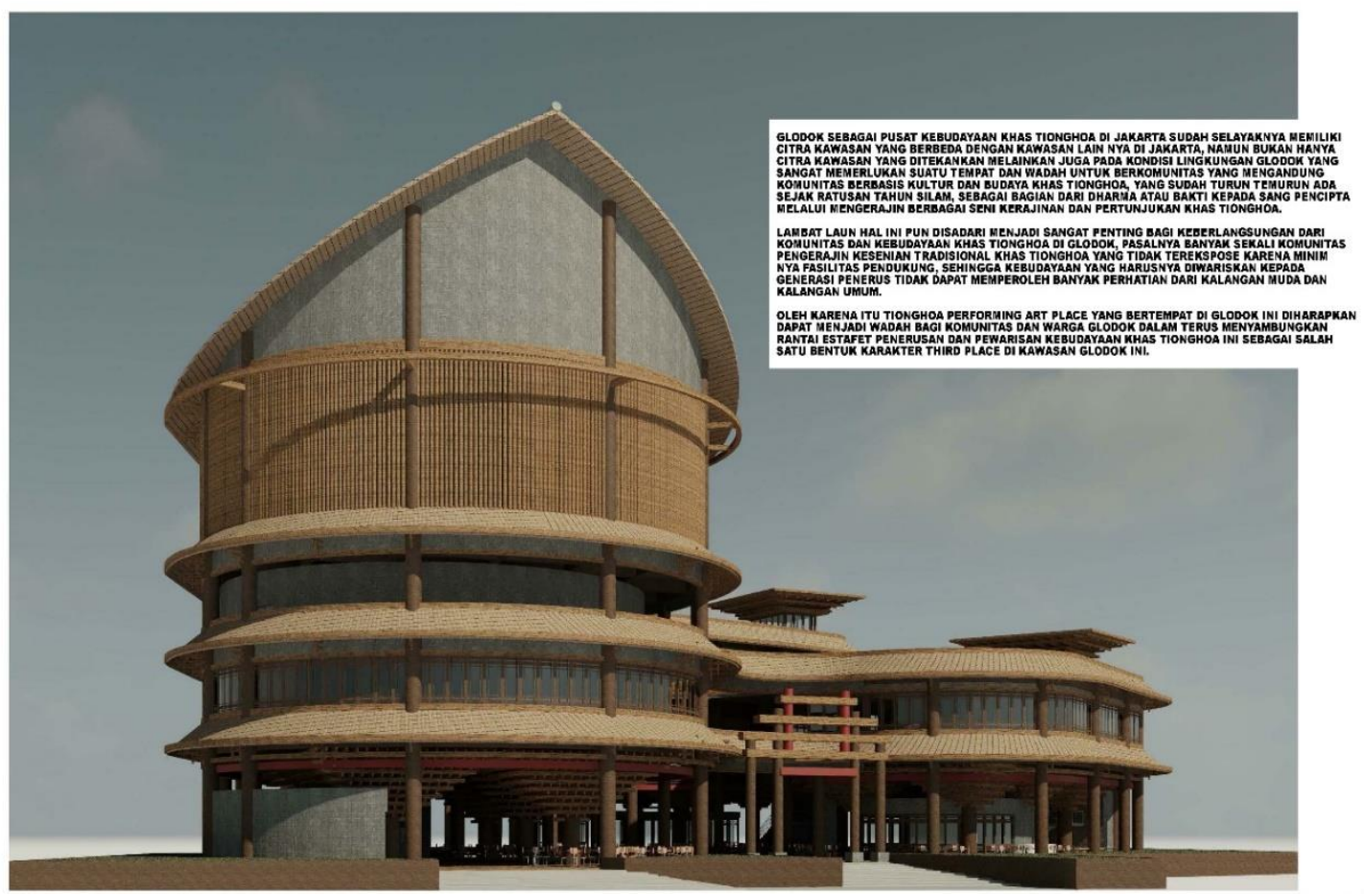

Di dalam proyek ini memiliki 2 lapis basement yang fungsi nya di khususkan untuk peletakan ruang service, mekanikal, elektrikal, plumbing, dan utilitas. Pada basement 2 murni dikhususkan untuk area service dan juga mekanikal, elektrikal, plumbing, mulai dari ruang GWT air bersih, STP, WTP, ruang pompa air bersih, GWT air kebakaran, ruang pompa air kebakaran, ruang exhaust dan ruang fan. Sedangkan basement 1 memiliki ruang kantor pengelola bangunan, ruang server, ruang genset dan travo, ruang panel utama, ruang penampungan dan pengolahan sampah, serta ruang exhaust dan fan, kedua level basement ini dilengkapi dengan lift dan tangga kebakaran, untuk memudahkan kegiatan service dan evakuasi darurat.

Pada lantai dasar mulai terlihat grid pembentuk bangunan yang dibagi menjadi 3 segmen masa yang disatukan di lantai 2 dan 3 nya, didapat grid seperti ini dikarenakan terjadinya pembentukan jalan lokal utama pada tapak yang menjadi pusat pertunjukan bagi barongsai dan liong yang menjadi atraksi utama pada proyek ini, menurut metode pertunjukan nya barongsai dan liong harus dipertunjukan pada jalan-jalan utama pada suatu desa atau kota sehingga berhubung tapak ini memiliki 2 muka jalan maka tapak dibelah untuk lewat nya barongsai dan liong pada saat pertunjukan di gelar, sehingga masa bangunan seluruh nya berorientasi penuh pada jalan yang membelah tapak.

Pada lantai dasar ini memiliki fungsi yang dominan untuk tea house atau restoran yang dapat dijadikan sebagai tempat duduk-duduk dan bersantai bagi warga Glodok, serta disamping itu pula terdapat workshop barongsai liong itu sendiri dan workshop keramik khas tradisional Tionghoa, kedua workshop ini diletakan pada lantai dasar dikarenakan material pembuatan nya serta proes pengerjaan nya yang tergolong kedalam pekerjaan berat sehingga diperhitungkan untuk faktor keselamatan dank e praktisan nya.

Pada lantai 2 ini merupakan lantai khusus workshop dan ruang latihan serta terdapat juga ruangan pendukung seperti retail komersil yang menjual hasil karya kerajinan seni khas Tionghoa, lantai 2 ini menghubungkan ketiga segmen dari bangunan ini, terdapat workshop pembuatan baju tradisional Tionghoa, ruang latihan seni music gambang kromong dan seni music tradisional Tionghoa lain nya, workshop wayang cokek dan potehi, workshop kaligrafi 
China, workshop lukisan Tionghoa, serta ruang untuk pembelajaran bahasa Mandarin. Semua nya dibuat system melingkar agar dapat terkoneksi dengan mudah dan tanpa terputus.

Pada lantai 3 ini adalah ruang transisi antara workshop dengan ruang pertunjukan di lantai 4 yang difungsikan menjadi ruang pameran dan galeri, untuk mempertunjukan hasil jadi dari seni kerajinan khas Tionghoa ini, galeri ini memiliki luasan $2 / 3$ dari luasan lantai $3,1 / 3$ nya difungsikan sebagai ruang olahraga dan seni bela diri khas Tionghoa secara terbuka / outdoor, memiliki luasan yang besar dikarenakan faktor lantai dasar yang di elevasi supaya memberikan kesan lantai itu tetap pada lantai dasar bangunan.

Pada lantai 4 ini adalah lantai dimana ruang pertunjukan berada, ruangan pertunjukan ini berada pada segmentasi bangunan yang paling luas guna dapat menampung banyak penonton yang akan menonton pertunjukan kesenian khas tradisional Tionghoa tersebut. Memiliki konfigurasi barisan penonton yang berundak semakin tinggi keatas, guna mendapatkan visibilitas yang baik kea rah panggung, kemudian area outdoor dapat digunakan untuk perkumpulan, antar komunitas jika diperlukan.

\section{KESIMPULAN DAN SARAN}

\section{Kesimpulan}

Tempat pertunjukan kesenian khas Tionghoa di Glodok ini menjadi one stop cultural center dimana proyek ini dapat menfasilitasi berbagai kegiatan kesenian tradisional khas China. Mulai dari proses di hulu seperti pembuatan produk kesenian khas China, sampai kepada proses tahap akhir seperti memamerkan, mempertunjukan, serta memperlombakan hasil dari kesenian tersebut. Sehingga komunitas pengerajin serta kesenian khas Tionghoa itu sendiri dapat semakin dikenal dan mendapat pengakuan dari penduduk kelurahan Glodok itu sendiri, dan pada akhir nya problematika dari eksistensi serta sulit nya mencari generasi penerus dari kesenian khas tradisional Tionghoa ini dapat teratasi oleh keterbukaan dan pengenalan lebih dekat kepada penduduk Glodok.

\section{Saran}

Perlu juga adanya dukungan dari pemerintah dalam mengemban tugas mengeksistensikan tradisi-tradisi mengerajin seni kesenian khas Tionghoa ini.

\section{REFERENSI}

Claudine, S. (1985). Sastra China Peranakan Dalam Bahasa Melayu. Jakarta : Balai Pustaka. Gisling. (2011). Zhenchenglou, a rotunda tulou in Yongding county, Fujian.

Oldenburg, R. (1999). The Great Good Place.

Sanmu, D. dan Shufa X. B. (1978). Hong Kong Taiping Book Department Publishing : Hong Kong Situs Pemerintah Kota Jakarta. (2009). Gambang Kromong.

Tionghoa info. (2012). Kesenian Barongsai, 24 Juni 2012:

https://www.tionghoa.info/barongsai/

Tionghoa info. (2015). Tarian Naga, 26 september2015 : https://www.tionghoa.info/tariannaga/

Utama, Wi. S. (2007). Kehidupan Sosial Budaya Masyarakat Tionghoa Di Batavia 1900-1930, 2627. 